\title{
Study on the factors of delay in construction works
}

\author{
Estudo sobre os fatores de atraso nas obras
}

\begin{abstract}
André Brasil Carvalho
Luiz Maurício Furtado Maués

Felipe de Sá Moreira

Caio José Losada Reis

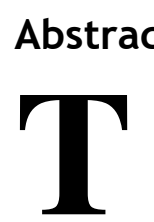

he delay in civil construction works is observed globally and affects the economy of countries. Therefore, identifying the causes of delays is of paramount importance to minimize their consequences. This paper aims at identifying the causes of delay in construction works and their analysis and existing correlations through statistical factor analysis. The research methodology included a Systematic Literature Review (SLR), a Survey Research through questionnaires and interviews was conducted, as well as the identification of the main causes of delay through the Relative Importance Index (RIL) and the ABC Curve. Finally, factor analysis of the causes of delay was performed, not limiting only to their identification. The results showed that the 12 identified causes are correlated to 4 delay factors, which account for $69.18 \%$ of the sample variance: supply management (21.41\%); workforce management (20,79\%); project management (17.64\%) and management of climatic conditions $(9.34 \%)$. It is concluded hereby that the delay factors mentioned herein can be considered management deficiencies in the projects and that the research has expanded the knowledge on construction delays, thus contributing to the frontier of knowledge to mitigate this problem in several countries, especially developing ones.
\end{abstract}

André Brasil Carvalho 1 Universidade Federal do Pará Belém - PA - Brasil

${ }^{2}$ Luiz Maurício Furtado Maués 2Universidade Federal do Pará Belém - PA - Brasil

${ }^{3}$ Felipe de Sá Moreira 3Universidade Federal do Pará Belém - PA - Brasil

${ }^{4}$ Caio José Losada Reis ${ }^{4}$ Universidade Federal do Pará Belém - PA - Brasil

Recebido em 06/05/20 Aceito em 26/01/21
Keywords: Factors of construction work delay. Factor analysis. Causes of delay. Project management.

\section{Resumo}

O atraso em obras é observado globalmente na construção civil e afeta a economia dos países, sendo fundamental a identificação de suas causas para a minimização das consequências. $O$ objetivo deste trabalho é a identificação das causas de atraso de obras em edificações e a análise de suas correlações pela análise fatorial estatística. A metodologia de pesquisa incluiu uma Revisão Sistemática da Literatura (RSL), uma Pesquisa Survey, por meio de questionários e entrevistas; assim como a identificação das principais causas de atraso pelo Índice de Importância Relativa (RII) e a Curva ABC. Por fim, efetuou-se a análise fatorial das causas de atraso; não se limitando apenas a identificação das mesmas. Os resultados demonstraram que as 12 causas identificadas são correlacionadas a 4 fatores de atraso, que explicam 69,18\% da variância da amostra: gestão de suprimentos (21,41\%); gestão da mão de obra (20,79\%); gestão do projeto $(17,64 \%)$ e gestão das condições climáticas $(9,34 \%)$. Conclui-se que os fatores de atraso citados podem ser considerados como deficiências de gestão dos empreendimentos e que a pesquisa aprofundou o conhecimento sobre atrasos na construção, contribuindo na fronteira do conhecimento para mitigação deste problema presente em vários países, principalmente os países em desenvolvimento.

Palavras-chave: Fatores de atrasos de obra. Análise fatorial. Causas de atraso. Gestão de projetos. 


\section{Introduction}

The delays in the delivery of work contracts still appear as a recurring issue in engineering projects, which often occur from design to completion, whether in public or private works, in developing or developed countries. The consequences are disputes and litigation between the parties, cost escalation, loss of profit, poor service quality, arbitrage, overrun of the deadline defined for executing the works or closing the project (AKOGBE; FENG; ZHOU, 2013; DOLAGE; PATHMARAJAH, 2015; GONZÁLEZ et al., 2014; GUNDUZ; NIELSEN; OZDEMIR, 2015; KHAN; GUL, 2017; MARZOUK; EL-RASAS, 2014; SWEIS, 2008; ULLAH et al., 2018). It is further observed that the delays in construction projects is a fact observed globally or on a large scale, affecting not only the industry itself, but the economy of nations in general; thus negatively impacting the success of the project due to changes in the original execution schedule and the previously established costs, quality criteria and management of safety conditions (CHAUHAN; SHAH; RAO, 2008; DORAISAMY; AKASAH; YUNUS, 2020; FARIDI; EL-SAYEGH, 2006; FLYVBJERG et al., 2002; MYDIN et al., 2014a).

Because this is one of the biggest problems in construction management, the delay in construction works poses a strong financial and social impact on all the stakeholders in the project. However, it is more intense and common in developing countries, which usually overrun project costs and have budget problems and shortage of resources (ABBAS; PAINTING, 2017; KAMING et al., 1997; RACHID; TOUFIK; MOHAMMED, 2018; SHEBOB; DAWOOD; XU, 2011). Venkatesh and Venkatesan (2017) also emphasize there is a variation in occurrence of the causes for delay among countries and that occurrences regarded as critical are very different in developing countries than those in developed ones.

In the Brazilian case, for example, Filippi and Melhado (2015) cite data from the Brazilian Consumer Association $(\mathrm{ABC})$, which found an increase of $65 \%$ in delays in works carried out in São Paulo during the years 2005 and 2010. In addition to also reporting the increase in the number of lawsuits between 2008 and 2013, which jumped from 140 new lawsuits against São Paulo construction companies to 3,779, that is, $2,600 \%$ more in just 5 years; according to a survey by Tapai Advogados, which works with real estate law. Corroborating the above, Maués et al. (2017) emphasize that the performance in the construction industry is much lower in terms of meeting contractual deadlines, especially in developing countries, if compared to other industries, such as the manufacturing industry. These authors researched 142 projects in the Brazilian Amazon region between the years 2005 and 2015, and found that $81.69 \%$ of the works suffered delays in their original schedules; which corresponded to 116 projects delivered after the deadline.

Other countries can be cited, such as the case of Iran, which presented a cost of approximately US \$ 21 billion to the government of that country regarding the delays in the works from 2002 to 2012; according to the Iranian statistical center (SAMARGHANDI et al., 2016). In Qatar, Senouci, Ismail and Eldin (2016) detail that the public projects carried out, between 2000 and 2013, presented a percentage of 54\% increase in costs and $72 \%$ of delays in the completion of the works; as well as an increase of $50 \%$ in relation to the cost and delays in the realization time in the case of building maintenance services. Mukuka, Aigbavboa and Thwala (2015) and Prasad et al. (2018) report, for instance, the challenge of the construction industry in South Africa and India to deliver works within the contractual deadline and the importance of adopting mitigation measures, and this is the subject of studies of the possible causes for delay in construction works.

Hsu, Aurisicchio and Angeloudis (2017) corroborate this thesis by stating that delays in engineering projects cause innumerable challenges and problems and greatly burden the works. And, therefore, the identification of the causes of non-compliance with the original schedule is essential to avoid the continuity of delays in other stages of construction or in new ventures. Sha et al. (2017) also consider for the elaboration of effective strategies to mitigate the consequences of delays in works, especially the extrapolation of costs, goes through the identification of their critical causes. Thus, it becomes paramount to identify the main causes for delays and to adopt preventive measures to minimize the impacts arising from such phenomena (ASNAASHARI et al., 2009; SHAHSAVAND; MAREFAT; PARCHAMIJALAL, 2018; YANG; CHU; HUANG, 2013).

Głuszak and Les̈niak (2015), as well as Kowalczyk et al. (2018) further clarify that the analysis of construction delays is still relevant for the construction sector, irrespectively of the studies conducted previously of the existing management tools and the expertise of engineers. However, according to Alsehaimi et al. (2013), although there are many studies that address the delay of works, most of them do not have objective guidelines on the increase of practical actions for managing the projects; in addition to the suggestions made usually being of a generalist nature and not specifically dealing with the causes of delay. 
In view of this context, the main objective of this paper is to identify the causes that contribute to the delay of works in the construction industry and the analysis of the roots and their negative consequences. Therefore, this paper seeks not only to identify the main causes for delays in construction works - a common objective in several research works - but also the study of the correlations among them through the statistical factor analysis technique, applied in the most varied types of constructions; including commercial, residential, public and industrial buildings. Unlike the work published by Maués et al. (2017), who used the same statistical technique, only for project variables and some management variables. Furthermore, the broad range of causes of delays in constructions from the original sample were classified hierarchically through the methodology of the ABC Curve and the Relative Importance Index (RII). This way, the authors seek to collaborate to further developing studies on construction delays by contributing to mitigating this problem in several countries, especially in developing ones.

\section{Delay in construction works}

It is noteworthy that early research on the topic considered work delays as non-excusable, compensable excusable, non-compensable excusable, and concurrent (ARDITI; ROBINSON, 1995). Keane and Caletka (KEANE; CALETKA, 2008) considered the delays as critical, non-critical or simultaneous, as well as dominant, subcritical or simply non-relevant; in case said delays have been caused by ineffective performance on one party.

In conceptual terms, the delay of a project can be defined as the extrapolation of the contract term for project completion or the period that exceeded the extension of the contract, granted by adding time to the final deadline or even beyond the date of delivery of the works, as agreed upon between the contracting party and the contractor (GÜNDÜZ; NIELSEN; ÖSDEMIR, 2013; TRAUNER et al., 2009). According to Hamzah et al. (2011), delays in construction works are inevitable and characterized by slower execution of a project when compared to the planned schedule or even by late completion of the projects. However, according to Agyekum-Mensah and Knight (2017), the delay in construction works is merely defined according to not meeting the original schedule, and it occurs due to several reasons, and can be originated by any of the stakeholders to the project.

Aibinu and Jagboro (2002) further explain that in project delay situations, a typical option is to execute the steps of the works faster or to extend their duration, obviously with subsequent escalation of costs and extension of the originally planned deadlines. In such cases, the standard is to manage this additional cost by including a percentage to the project value in the form of a provision or share in the budget sheet prepared prior to the construction work contract. According to Yang and Wei (2010), the delays in construction works can take place in any step in the construction works, although researchers emphasize that the planning and design phases significantly influence the cost and schedule of the works. Consequently, delays during project planning usually hamper the construction schedule in the ensuing phases, taking into account the completion date for the project.

In relation to the causes of delay, they can be identified as internal and external; whereas those related to customers, designers, service providers and consultants are regarded as internal causes, while the external causes are related to climate issues, suppliers and the government (AHMED; AZHAR; KAPPAGANTULA, 2003; RAFIEIZONOOZ et al., 2015). The following are among the most relevant causes:

(a) the financial difficulties of customers and/or owners (CHALLAL; TKIOUAT, 2012; FUGAR; AGYAKWAH-BAAH, 2010; LARSEN et al., 2016; MEGHA; RAJIV, 2013);

(b) the scope changes required (MUHWEZI; ACAI; OTIM, 2014; TAFAZZOLI; AP; SHRESTHA, 2017; TARIGAN; SUBROTO, 2018; VACANAS; DANEZIS, 2018);

(c) poor management of the construction site (AZIZ, 2013; ILYAS; LI; ULLAH, 2020; SEPASGOZAR; RAZKENARI; BARATI, 2015);

(d) slow or delayed decision making (ALAGHBARI et al., 2007; KHARASHI et al., 2009);

(e) poor project planning (DUY; OGUNLANA, 2004; KHOSHGOFTAR et al., 2010);

(f) inefficient coordination and communication among the parties (HWANG; ZHAO; NG, 2013; TOOR; OGUNLANA, 2008);

(g) low availability and productivity of labor (ABDUL-RAHMAN et al., 2006; KUMARASWAMY; CHAN, 1998); and 
(h) late delivery or poor quality of materials (KOUSHKI; KARTAM, 2004; RAHMAN et al., 2017).

Also, there are unpredictable events, poor technical capacity of local teams of contractors or consultants, poorly designed projects, adverse climatic conditions, increased production, among other causes of delay (AL-MOMANI, 2000; BIRGONUL; DIKMEN; BEKTAS, 2015; HASEEB; BIBI, 2011). Gebrehiwet and Luo (2017) also highlight corruption, inflation and unavailability of supplies in the construction sites as causes of delay in services.

However, most of the studies in the area mention inefficient management and coordination in construction projects are reported as one of the main causes adding to the delay of construction works (ALSEHAIMI; KOSKELA; TZORTZOPOULOS, 2013; MUIANGA; GRANJA; RUIZ, 2015; ZIDANE et al., 2015). It is further observed by Filippi and Melhado (2015) that the companies delay their construction works basically due to non-observance of the previously established planning, obtaining no intrinsic benefit therefrom. And according to Adam and Josephson (2017), efficient project management is a key factor with an impact on decision-making adopted in the early phases of the project concerning the construction cost and schedule criteria.

It should finally be emphasized that a large part of the authors that were surveyed is restricted only to cataloging and description of countless causes of delay in construction works without aiming at a broader understanding of this phenomenon through factor analysis of their causes. This observed knowledge gap limits the studies in the area and is configured as one of the main objectives of this paper.

\section{Methods}

The adopted research methodology can be classified, in relation to approach, as a quantitative research and according to the objectives, this paper represents an exploratory and explanatory research, as it pursues greater understanding of the problem, which makes it more explicit, thus helping build up hypotheses (GIL, 2002). Regarding this matter, Fellows and Liu (2015) highlight that both approaches tend to be exploratory both the quantitative procedure, which uses the scientific method, and the qualitative procedure, whereby the theme is studied, often without having the research formulations been previously established. Thus, aiming at reaching the research objectives, the proposed methodology was developed in the following steps:

\section{Systematic Literature Review (SLR)}

The SLR was developed between March 4 and May 312019 to identify the most frequent causes related to the construction work delays found in the literature. The advantages of the SLR include the traceability of the process, the grounds on a specific strategy, their reproducibility and application through explicit and systematized search methods, thus allowing for objective criticism and analysis (GREEN et al., 2008; SAMPAIO; MANCINI, 2007).

In sum, four steps made up the SLR, namely:

(a) definition of research parameters (bases, key words, language of the studies, and inclusion and exclusion criteria);

(b) the actual search for publications, identifying possible duplicates (which are immediately removed);

(c) the selection of publications, identifying adherence to the topic of the SLR by assessing the titles and abstracts according to the inclusion and exclusion criteria (previously stipulated); and

(d) the data extraction step, which takes place after the complete reading of the publication.

In the latter step, application of the inclusion and exclusion criteria is repeated, since at this point the work is recognized in full.

The method that was applied in the SLR starts with an exploratory study aiming at better knowledge of the research related to the topic and at defining the search parameters. The research bases that were used included: Science Direct, Web of Science, Scielo and Engineering Village; which were defined according to the recommendations by Dresch, Lacerda and Antunues Júnior (2015), and according to the empirical knowledge of the authors. The following terms were searched: "delays in construction industry", "construction delays", "construction industry delays", "construction sector delays" and "delays in construction". The researches were conducted in the fields title, abstract and keywords using the "OR" Boolean operator between the research terms. It should be emphasized that there was no limitation as to the 
language or the period of publication. However, papers should have the title or abstract in English, at least, since the search terms were in English. The following exclusion criteria were adopted:

(a) import errors;

(b) literature review papers;

(c) editorials, abstracts and calls for congresses, conferences, and journals;

(d) publications that do not represent causes for construction delays;

(e) publications unavailable for research; and

(f) publications with 2 pages or less.

Finally, the following data were extracted from each paper in the extraction phase: paper title, authors, year of publication, country where the research was conducted, and the causes for delay indicated by the authors.

By strictly observing the review steps and the acceptance criteria for the publication, papers and causes related specifically to the delays in the construction industry were obtained. Finally, the steps of research are presented in Figure 1.

\section{Survey research}

It should be emphasized that, according to Freitas et al. (2000), the selection of the appropriate research method must be in line with the objectives of the work; whereas according to Dresch, Lacerda and Antunues Júnior (2015), the Survey research features a quantitative approach and one of its specific goals is to generate reliable data that allow for a robust statistical analysis, in addition to exploring, describing and explaining a phenomenon or a given population. This way, conducting a Survey research in the data collection step in this paper was decided in order to identify the more frequent possible causes of construction work delays.

\section{Figure 1 - Steps of the research}

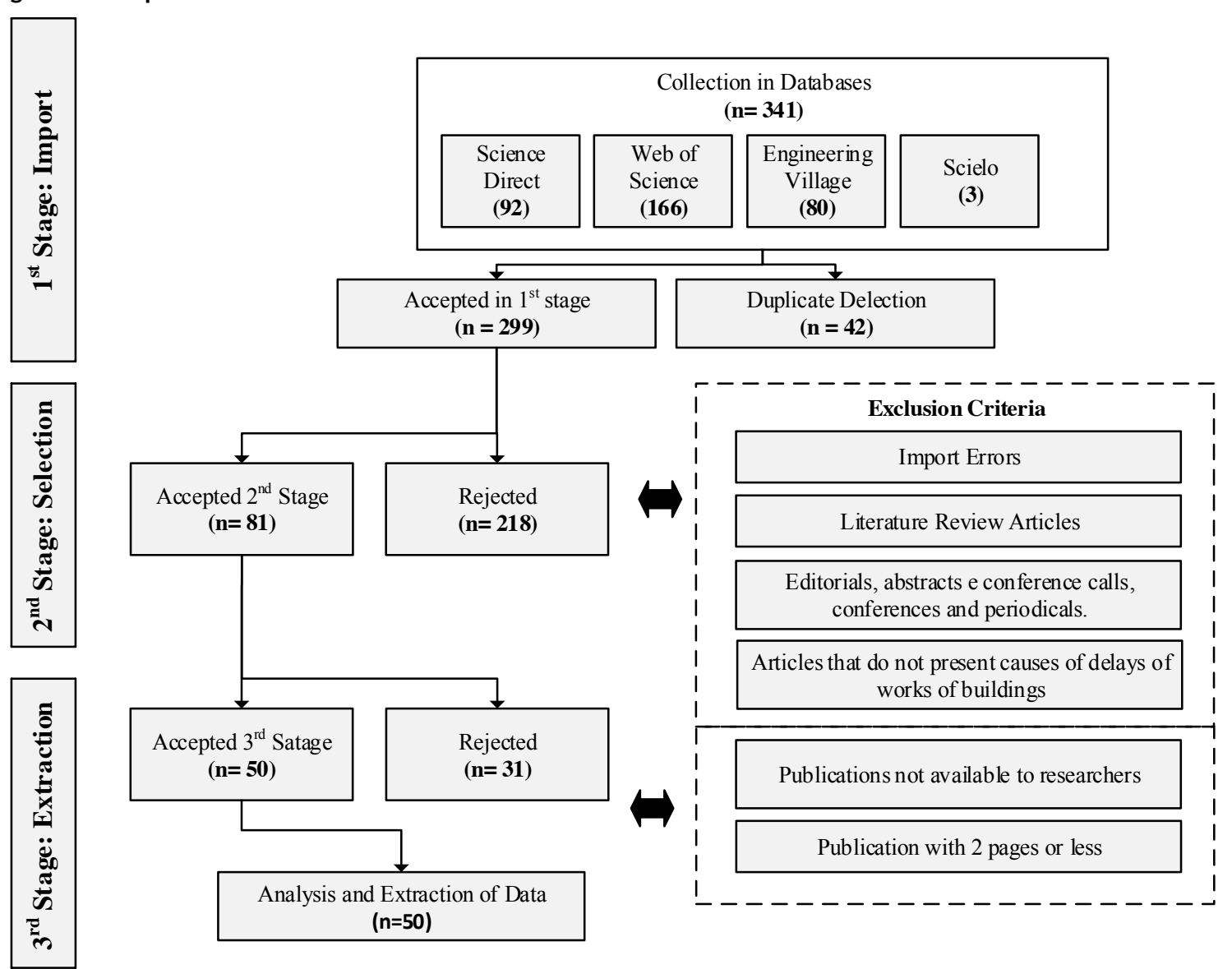


To this end, preliminarily, a bibliographic research on the delay of works was carried out, aiming to obtain the most relevant research that addressed this theme. Among the various authors analyzed, the work of Reis et al. (2016), who identified 56 reasons for the most common delay in construction projects, in addition to having identified and hierarchically classified the delay factors in line with the literature and data obtained from a Survey carried out in the engineering market in the metropolitan region of Belém.

Therefore, it is emphasized that the present work is an in-depth study of Reis et al. (2016) and started from the results obtained from a questionnaire prepared by the aforementioned researchers, which was organized in eight groups:

(a) project feasibility and initial documentation;

(b) project management throughout the works, (technical consultation and amendments);

(c) owner (customer);

(d) construction company (administrative, management and execution);

(e) labor;

(f) materials;

(g) equipment; and

(h) external factors.

The strategy to apply the questionnaire was through interviews, either in person or via e-mail.

The sample being surveyed was made up by 83 construction industry professionals in the metropolitan area of Belém. It should be noted, therefore, that the objective was to verify the impact in the Amazon region of the causes of the delay identified in the literature and which were also observed by the interviewees, who analyzed the level of significance of the causes of delay, which were organized in a Likert scale with 5 options of answers, namely:

(a) little (1);

(b) little to medium (2);

(c) medium (3);

(d) medium to high (4); and

(e) high (5).

\section{Identification of the main causes of construction delays}

In order to rank the results that were obtained in the survey, the relative importance index (RII) of each of cause of delay is based on the frequency of occurrence of said causes. Then, the causes of work delays could be identified through stratification by the highest RII values, and by using the ABC Curve methodology the main causes of construction delay could be identified and grouped in class A of the $\mathrm{ABC}$ Curve, corresponding to approximately $30 \%$ of the total sample value.

According to Mota et al. (2012), the main objective of the ABC Curve is to help in decision making and quick action by the managers, thus providing for a great positive impact on the final result of the company. The researchers also affirm this methodological tool has both internal and external factors related to the company's policy and culture, including the region and its operation market, which influence management and classification thereof.

It should also be emphasized that, according to Martins and Alt (2009), the items in class A of the ABC Curve are the most significant ones and may account for $35 \%$ to $70 \%$ of the total sample value, while those in class B are considered intermediate (10\% to $45 \%)$, and the remaining (less important) ones would be placed in class C. However, according to Ballou (2006), there is neither an exact way of grouping the items into any of the categories nor to determine the number of categories to be used.

\section{Factor analysis}

After this step, the factor analysis of the identified causes of delay was performed in order to identify the correlation between them. According to Fávero et al. (2009, p. 236), factor analysis "[...] is a multivariate statistical technique aimed at reducing data and creating indicators that represent original variables.". Still

32 Carvalho, A. B.; Maués, L. M. F.; Moreira, F. de S.; Reis, C. J. L. 
according to these authors, the use of factor analysis is based on the assumption of the existence of a correlation between the original variables and the sharing of one or more factors, which explain the relationship between said variables. It is also worth noting that according to Hair Junior et al. (2009), the sample size should never be less than 50 observations; otherwise, conducting a factor analysis would be difficult.

As discussed in the literature, there are countless causes that can contribute to the delay of work, so the use of factor analysis was used to group these causes into factors, since these causes of different origins may converge or contribute to one for the same most comprehensive group.

\section{Results}

\section{SLR Results}

The most relevant authors found in the 50 publications are listed in Table 1, which also provides an overview of the major countries where the studies were developed and where the largest number of publications occurs.

When analyzing the frequency of publications of these studies, a significant increase in the number of papers, especially over the last seven years, is observed. Indeed, between 1995 and 2003 there were 5 publications; while from 2004 to 2011, 12 papers were published; and from 2012 to the current year (2019), more than 33 research papers have been published. It is important to highlight that these results refer to cases of delays in (residential or commercial) construction works, that is, no delays related to infrastructure services were addressed. Such limitation directly interferes with the amount of studies reviewed in this SLR.

\section{Survey research results}

The partial results of the Survey are shown in Table 2, which exhibits the 12 main causes of work delays ranked by the higher values of the relative importance index (RII) and stratified by the ABC curve, which are classified in group A. The identified causes of delay account for $30.77 \%$ in relation to the original sample, which was made up by 55 variables. The accumulated values of the RII and the percentage of representativeness of each cause of delay are also represented.

Table 1 - Main countries, authors and frequency percentage

\begin{tabular}{l|l|c}
\hline Countries & \multicolumn{1}{|c}{ Authors } & \multicolumn{1}{c}{$(\mathbf{c})$} \\
\hline Iran & $\begin{array}{l}\text { Asnaashari } \text { et al. (2009), Pourrostam and Ismail (2011), Pourrostam, Ismail and } \\
\text { Mansourenejad (2011a, 2011b), Saeb, Khayat and Telvari (2016) and } \\
\text { Shahsavand, Marefat and Parchamijalal (2018) }\end{array}$ & 12.0 \\
\hline Turkey & $\begin{array}{l}\text { Bilgin, Dikmen and Birgonul (2018), Birgonul, Dikmen and Bektas (2015), } \\
\text { Gunduz, Nielsen and Ösdemir (2013, 2015) and Kazaz, Ulubeyli and Tuncbilekli } \\
(2012)\end{array}$ & 10.0 \\
\hline Egypt & $\begin{array}{l}\text { Aziz (2013), El-Razek, Bassioni and Mobarak (2008), Marzouk and El-Rasas } \\
(2014) \text { and Marzouk, El-Dokhmasey and El-Said (2008) }\end{array}$ & 8.0 \\
\hline USA & $\begin{array}{l}\text { Arditi and Robinson (1995), Trauner } \text { et al. (2009), Arditi, Nayak and Damci } \\
(2017) \text { and Kog (2018) }\end{array}$ & 8.0 \\
\hline India & $\begin{array}{l}\text { Rathinakumar, Vignesh and Dhivagar (2017), Doloi } \text { et al. (2012) and Hasan and } \\
\text { Jha (2019) }\end{array}$ & 6.0 \\
\hline Malaysia & Abdul-Rahman et al. (2006), Hasmori et al. (2018) and Mydin et al. (2014b) & 6.0 \\
\hline Pakistan & $\begin{array}{l}\text { Gardezi, Manarvi and Gardezi (2014), Khahro and Memon (2018) and Khan and } \\
\text { Gul (2017) }\end{array}$ & 6.0 \\
\hline
\end{tabular}


Table 2 - Most relevant causes of construction work delays

\begin{tabular}{c|l|c|c|c|c}
\hline Item & \multicolumn{1}{|c|}{ Causes of delay } & RII & RII - Accum. & \% Accum. & ABC Curve \\
\hline 1 & $\begin{array}{l}\text { Delay in delivery of materials, } \\
\text { inefficiency of the purchasing sector }\end{array}$ & 0.716418 & 0.71641791 & $3.09 \%$ & $\mathrm{~A}$ \\
\hline 2 & $\begin{array}{l}\text { Delay in delivery of materials by } \\
\text { suppliers }\end{array}$ & 0.698507 & 1.414925373 & $6.11 \%$ & $\mathrm{~A}$ \\
\hline 3 & $\begin{array}{l}\text { Rework due to errors during } \\
\text { construction }\end{array}$ & 0.629851 & 2.044776119 & $8.83 \%$ & $\mathrm{~A}$ \\
\hline 4 & $\begin{array}{l}\text { Delay in payments throughout the } \\
\text { project, customer's financial difficulty }\end{array}$ & 0.626866 & 2.671641791 & $11.54 \%$ & $\mathrm{~A}$ \\
\hline 5 & Low level of labor productivity & 0.602985 & 3.274626866 & $14.15 \%$ & $\mathrm{~A}$ \\
\hline 6 & Lack of workforce commitment & 0.597015 & 3.871641791 & $16.72 \%$ & $\mathrm{~A}$ \\
\hline 8 & Delivery of incomplete projects & 0.59403 & 4.465671642 & $19.29 \%$ & $\mathrm{~A}$ \\
\hline 9 & Increase of services (project changes) & 0.561194 & 5.026865672 & $21.72 \%$ & $\mathrm{~A}$ \\
\hline 10 & Shortage of construction materials & 0.528358 & 5.555223881 & $24.00 \%$ & $\mathrm{~A}$ \\
\hline 11 & $\begin{array}{l}\text { limate/Weather conditions (heat, } \\
\text { rain etc.) }\end{array}$ & 0.525373 & 6.080597015 & $26.27 \%$ & $\mathrm{~A}$ \\
\hline 12 & Delays in works by workforce & 0.522388 & 6.602985075 & $28.52 \%$ & $\mathrm{~A}$ \\
\hline
\end{tabular}

\section{Factor analysis results}

As discussed in the section on research methodology, factor analysis was used in the treatment of the collected data. And among the statistics to check the correlation matrix and the FA adequacy, the KaiserMeyer-Olkin (KMO) test and the Bartlett's Test of Sphericity (BTS) are used, the results of which being exhibited in Table 3. Thus, according to the criteria of the statistical tool, the KMO value found (0.761) corresponds to a mean factor analysis; since the values close to 0 indicate a weak correlation between the variables and the closer to 1 they are, the stronger the correlation. Regarding the Barlett's Test of Sphericity applied, the obtained result (0.001) shows that the factor analysis is adequate, since the null hypothesis was rejected and there are indications that there are significant correlations between the original variables (FÁVERO et al., 2009).

Afterwards, the total explained variance of the sample was conducted, as shown in Table 4. The results showed that the 12 identified causes of delay are correlated to only 4 delay factors, which account for $69.179 \%$ of the variance of the original data and have the eigenvalues of their components with significance, that is, greater than 1 . It should be noted that the factor analysis aims at changing one set of values into factors, that is, the goal of the method is to explain the largest part of the data variance.

Regarding the correlation matrix analysis, the results demonstrated that the causes of delay with the highest correlation are related to problems with supplies and difficulties with labor, as per the correlation indexes of the most significant variables, namely:

(a) delay in delivery of materials, inefficiency of the purchasing sector/delay in delivery of materials by suppliers - correlation index of variables: 0.686;

(b) low level of labor productivity/lack of commitment by the workforce - variable correlation index: 0.696;

(c) low level of labor productivity/labor delays - variable correlation index: 0.674;

(d) dack of labor commitment/low level of labor productivity - variable correlation index: 0.696;

(e) delay in delivery of materials by suppliers/delay in material delivery, inefficiency in the purchasing sector - correlation Index of variables: 0.686;

(f) delayed delivery of materials/shortage of construction materials - correlation Index of variables: 0.610;

(g) labor delays/low level of labor productivity - correlation Index of variables: 0.674; and

(h) shortage of construction material/delay in material delivery - correlation Index of variables: 0.610.

Finally, intending to help interpret the resulting factors in the extraction phase, the analysis of the rotational component matrix was performed (Table 5). 
As shown in Table 5, the variables that make up the factors can be seen and that each variable has only one significant load factor for each of the factors. This way, the interpretation and identification of the construction work delay factors is facilitated.

Table 3 - KMO and Bartlett's tests

\begin{tabular}{l|c}
\hline \multicolumn{1}{c|}{ Reliability } & Results \\
\hline Kaiser-Meyer-Olkin (KMO) measurement of sampling suitability & 0.761 \\
Barlett's Test of Sphericity (BTS) - Significance & 0.000 \\
Chi-square X & 308.355 \\
Degree of freedom & 66 \\
\hline
\end{tabular}

Table 4 - Total variance explained

\begin{tabular}{|c|c|c|c|c|c|c|c|c|c|}
\hline \multirow{2}{*}{ Var. } & \multicolumn{3}{|c|}{ Initial own values } & \multicolumn{3}{|c|}{$\begin{array}{c}\text { Square load extraction } \\
\text { sums }\end{array}$} & \multicolumn{3}{|c|}{ Square load rotating sums } \\
\hline & Total & $\begin{array}{c}\% \\
\text { variance }\end{array}$ & $\begin{array}{c}\% \\
\text { accum. }\end{array}$ & Total & $\begin{array}{c}\% \\
\text { variance }\end{array}$ & $\begin{array}{c}\% \\
\text { accum. }\end{array}$ & Total & $\begin{array}{c}\% \\
\text { variance }\end{array}$ & $\begin{array}{c}\% \\
\text { accum. }\end{array}$ \\
\hline 1 & 4.403 & 36.689 & 36.689 & 4.403 & 36.689 & 36.689 & 2.569 & 21.407 & 21.407 \\
\hline 2 & 1.654 & 13.781 & 50.470 & 1.654 & 13.781 & 50.470 & 2.495 & 20.792 & 42.198 \\
\hline 3 & 1.241 & 10.340 & 60.810 & 1.241 & 10.340 & 60.810 & 2.116 & 17.637 & 59.835 \\
\hline 4 & 1.004 & 8.369 & 69.179 & 1.004 & 8.369 & 69.179 & 1.121 & 9.344 & 69.179 \\
\hline 5 & 0.921 & 7.674 & 76.854 & & & & & & \\
\hline 6 & 0.780 & 6.502 & 83.356 & & & & & & \\
\hline 7 & 0.524 & 4.367 & 87.723 & & & & & & \\
\hline 8 & 0.391 & 3.254 & 90.977 & & & & & & \\
\hline 9 & 0.350 & 2.920 & 93.897 & & & & & & \\
\hline 10 & 0.305 & 2.541 & 96.438 & & & & & & \\
\hline 11 & 0.231 & 1.929 & 98.367 & & & & & & \\
\hline 12 & 0.196 & 1.633 & 100.00 & & & & & & \\
\hline
\end{tabular}

Note: Extraction Method - Principal Component Analysis.

Table 5 - Rotational component matrix

\begin{tabular}{|c|c|c|c|c|}
\hline \multirow{2}{*}{ Causes of delay } & \multicolumn{4}{|c|}{ Component } \\
\hline & 1 & 2 & 3 & 4 \\
\hline Delay in delivery of materials by suppliers & 0.866 & & & \\
\hline Shortage of construction materials & 0.759 & & & \\
\hline $\begin{array}{l}\text { Delay in delivery of materials - inefficiency of the purchasing } \\
\text { sector }\end{array}$ & 0.691 & & & \\
\hline Rework due to errors during construction & 0.595 & & & \\
\hline Low level of labor productivity & & 0.893 & & \\
\hline Delay in labor works & & 0.811 & & \\
\hline Lack of workforce commitment & & 0.802 & & \\
\hline Delivery of incomplete projects & & & 0.868 & \\
\hline Increase of services (project changes) & & & 0.774 & \\
\hline $\begin{array}{l}\text { Delay in payments throughout the project, customer's financial } \\
\text { difficulty }\end{array}$ & & & 0.568 & \\
\hline Difficulties in obtaining funding for the project & & & 0.395 & \\
\hline Climate/weather conditions (heat, rain etc.) & & & & 0.960 \\
\hline
\end{tabular}

Notes: Extraction Method: Principal Component Analysis.

Rotational Method: Varimax with Kaiser Normalization.

Rotation converged in 5 iterations. 
Next, the 4 factors were identified and interpreted as follows:

(a) Factor I - Supply Management: delay in delivery of materials, shortage of construction materials, delay in delivery of materials/inefficiency of the purchasing sector and rework due to errors during construction;

(b) Factor II - Labor Management: low level of labor productivity, delay in labor works and lack of workforce commitment;

(c) Factor III - Project Management: delivery of incomplete works, increase in services (project changes), delay in payments throughout the work, customer's financial difficulties and difficulties in obtaining financing for the project;

(d) Factor IV - Management of Climate Conditions: weather conditions (heat, rain etc.).

Finally, in order to measure the reliability of the factor statistical analysis, Cronbach's Alpha Test was conducted and produced the results shown in Table 6 . It can be seen that the value 0.857 of the coefficient is found to be in line with the minimum value acceptable in the literature, which is 0.70 (TORRES; MONTEIRO; ARICA, 2010).

\section{Discussion}

Considering the results presented and aiming at a more specific analysis of each identified delay factor, the understanding the fundamental causes that influence the occurrence of the event by the corresponding factor was pursued; the causes of delay, organized in their respective factors and according to the percentage of frequency of occurrence obtained, being identified as follows.

\section{Factor I: supply management}

This factor represents $21.407 \%$ of the total variance (refer to Table 4 ) and is made up by the following variables.

\section{Delay in delivery of materials (inefficiency of the purchasing sector)}

This cause has a load factor of 0.866 and is related to the inefficiency of the purchasing sector of the companies, which is responsible for the supply management of the works, including the contracting of suppliers, breaking down the pre-established conditions of delivery deadlines and costs for supplying the materials. And in the event that the criteria established for the contracting of these suppliers are not adequate, there may occur delays in the delivery of materials or supply of products that do not meet the minimum quality specifications by companies that do not have the necessary infrastructure for the correct fulfillment of the construction schedule.

In relation to the above, Hwang, Zhao and $\mathrm{Ng}$ (2013) state that the availability of materials at the construction site is considered to be one of the critical factors affecting the performance of the public housing sector schedule in Singapore; the authors further recommend that contractors should make longterm contracts to reduce the impact of uncertainties and potential risks of availability and prices of materials and equipment. It is also worth noting that according to Serna et al. (2018) the lack of materials needed in the project in the scheduled period is characterized as one of the most influential factors regarding the cost variance in the projects and may indicate lack of planning and, mainly, control by the professionals.

Table 6 - Reliability statistics

\begin{tabular}{l|c}
\hline \multicolumn{1}{c|}{ Reability testes } & Results \\
\hline Cronbach's Alpha & 0.857 \\
Cronbach's Alpha, based on standardized items & 0.857 \\
Number of items & 12 \\
\hline
\end{tabular}




\section{Delay in delivery of materials by suppliers}

The load factor for this cause is 0.759 and its focus is on the deficiencies alluding to suppliers of materials to the works, that is, they can be related to delays in the delivery of materials due to poor management, poor planning, inadequate logistics, amongst other factors that lead to the disorganization of the executive process of these companies. It should be emphasized, therefore, that the performance of the supply sector of the company responsible for the enterprise is not considered in the analysis of this cause, regardless of whether or not this action is effective.

According to Enshassi, Alnajjar and Kumaraswamy (2009), the main causes that influence the delays in construction works are related to lack of materials in the markets, shortage of construction materials in the construction site and delays in the delivery of materials for the construction works. And according to Ogunlana, Promkuntong and Jearkjirm (1996) the adequate supply of materials is a fundamental precondition, which is present in almost all construction activities, while the shortage of construction materials could cause the project to be delayed and consequently closed.

\section{Rework due to errors during construction}

This cause has a load factor of 0.691 , being related to the need to redo a previously performed service due to failures during the execution thereof. The reasons for this phenomenon may be the use of materials out of the design specifications, that is, materials with lower-than-required performance, inadequate dimensions or which have poor quality. According to Pereira et al. (2011), rework in civil construction negatively impacts the work schedule due to the delay that is generated, as well as the financial losses arised. Still according to the researchers, the types of rework identified include the delay prompted by defective material being delivered and the changes in the type of material and specifications during the construction.

\section{Shortage of construction materials}

The cause for shortage of materials has a load factor of 0.595 and is related to the small amount of a given type of supply at the construction site. There is a number of reasons for said shortage; and this may be a consequence of logistics, waste of material during the execution of the works, and, in this case, due to losses. There is also the possibility of theft or the purchased quantity of the input to have been badly estimated due to errors in budget calculations; for example.

Within this context, Asnaashari et al. (2009) report that there are several problems in the procurement of materials, components and machines that can bring about delays and that the most serious problem is the lack of cement, steel and concrete, which are considered critical inputs to the works. Corroborating with this assertion, Sambasivan and Soon (2007) consider that the lack of basic materials may prompt significant delays in the projects, especially when the demand exceeds the supply.

\section{Factor II: labor management}

This factor accounts for $20.792 \%$ of the total variance, being made up by the following variables.

\section{Delays in labor works}

Delays in the works, pertaining to labor, have a load factor of 0.893 and may be related to inadequate work methods adopted in productive processes, including construction techniques, workforce training and the equipment available for the services; which compromises safety and quality standards and consequently affects productivity; which Doloi et al. (2012) proved in their research.

Another issue to be considered is the inadequate sizing of work teams or even the shortage of labor, which according to Abdul-Rahman et al. (2006) is one of the major causes of work delays. These researchers also highlight the need for greater investment in improving the expertise and skills of human resources to minimize the construction work delay phenomenon.

Finally, one cannot but mention absenteeism, bad organizational climate, alcoholism, depression, as well as workplace accidents, which may lead to a total or partial cessation of activities. Kiviniemi et al. (2011), for example, mention that in 2008 there were 35.2 accidents involving construction workers in Finland and that it resulted in at least four days of employee absence from work. 


\section{Lack of workforce commitment}

The aforementioned cause has a load factor of 0.811 and is related to the non-professional conduct adopted by some of the company's workers, whether an employee or a contractor, which contributes to the delay of the services in the project. In this case, negligent, disrespectful and non-aligned (focused) behaviors are included in their functions and activities designated by the management of the works. On this aspect, Doloi et al. (2012) state that one of the most critical factors of construction work delays is the absence of commitment.

While Iyer and Jha (2005) warn that to achieve the completion of the work within the contractual term for any project, the commitment of everyone involved in it is essential. Finally, Arantes, Silva and Ferreira (2015) recommend that greater attention be given to the lack of communication and commitment by subcontractors, as these are relevant causes of work delay and that they impact on all other identified causes.

\section{Low level of labor productivity}

The cause of low labor productivity has a load factor of 0.802 and may be related to inadequate (or nonexisting) training to perform their activity, inefficient work methods, and failures to select or recruit an employee who is not qualified for the job; said conditions being corroborated by Dolage and Pathmarajah (2015).

In relation to low labor productivity, Palikhe, Kim and Kim (2018) state that this is one of the most significant issues in the construction industry because it directly affects the cost and enables the occurrence of delays in work schedule. The authors also report that the main causes affecting workers' productivity include the lack of financial incentives, unavailability of tools, not enough periodic meetings, and unsafe work conditions.

The influence of inspection that is not very demanding on the performance of the workforce should also be considered, as well as the absence of a compensatory financial mechanism for the execution of a job, such as payment for production results; as demonstrated in the research of Odeh and Battaineh (2002). Other relevant reasons include organizational culture and climate, and Arditi et al. (2017) emphasize that organizational culture is one of the causes of delay in construction projects and that it is important that the organizational culture is aligned with the local culture of the country.

\section{Factor III: project management}

This factor accounts for $17.637 \%$ of the total variance, involving the following variables.

\section{Delivery of incomplete projects}

The lack of information or deficient breakdown of the projects has a load factor of 0.868 and corroborates for the delay in construction works due to possible difficulties of interpretation and occurrences of errors, a frequent practice being the delivery of some projects or complementary parts still during the construction work execution phase. This situation could be avoided or minimized by taking management actions that allow for meeting the deadlines for project delivery, as well as the collaboration between the designers and engineers of the company in the preparation of project parameters and the planning of the project.

This theme was approached by Kog (2018), who identified as the main cause of construction work delay the late issuance of incomplete instructions, information or drawings, the preparation of inadequate drawings and delay in the revision and completion of the project. In addition, Santos, Starling and Andery (2014) observed in his research that the main problem in the contract amendments of periods, consequence of the delay in construction works, is related to deficiencies in the projects, more specifically the lack of compatibility, insufficient specification and unsatisfactory breakdown.

Khanzadi et al. (2019) further emphasize the complexity of the processes related to the projects, highlighting the various existing interconnected jobs as well as their variability and unpredictability, and that would bring about variations and delays found in the schedules.

\section{Increase of services (project changes)}

Projects changes have a load factor of 0.774 and may occur due to several factors, such as technical issues, economic circumstances, and even at the customers' request. And regardless of the existing context, when any changes in projects occurs, there will be an increase in services due to the need to adapt the production 
system to the proposed change, including the costs and deadlines involved in this new scenario. Consequently, the construction work will be delayed.

In this scenario, Tarigan and Subroto (2018) mention that one of the main causes of construction work delays is the requests for work changes by the owner during the construction phase, as well as with the changes/errors in the project documents, according to Marzouk, El-Dokhmasey and El-Said (2008). There is also research by Kazaz, Ulubeyli and Tuncbilekli (2012), who identified design and material changes as the most significant factor of construction work delay.

\section{Delay in payments throughout the project (customer's financial difficulty)}

The delay in payments throughout the work, due to financial difficulties experienced by the customer, has a load factor of 0.568 and this is possibly a significant cause of delay of construction works, as it can promote tensions and distress on the relations between the contracting company and its employees, suppliers and stakeholders. The immediate results include noncompliance with the goals, cost increases due to the variation in team productivity, possible claims, standstills or even workers' strike; besides the interruption in the supply of the inputs for the works.

Within this context, Park et al. (2019) state that the two risk factors with the highest impact on the construction management companies are project delay and payment delay; and that is characterized as a financial difficulty under the responsibility of the project owner and which affects the company's operation. As a result, Assaf and Al-Hejji (2006) point out that payment to contractors, without delay, for the services performed is fundamental in order not to hinder the ability of contractors to finance the works. The respective authors also point out that one of the significant causes of delay is the fact that, in the biddings, companies with the lower value propositions are contracted; this may preclude work completion in certain situations - something also observed by Abbasnejad and Moud (2013).

\section{Difficulties in obtaining funding for the project}

This cause has a load factor of 0.395 and will have more or less importance, within the context of the execution of the project within the contractual terms due to the size of the works and the economic conditions of the company, that is, its capability to carry out the services without resorting to a financial institution. Delay in the execution of the works may occur if the company does not have sufficient financial reserves and the requested funding is not approved or if it takes time to be obtained.

Regarding this theme, El-Razek, Bassioni and Mobarak (2008) point out that the two main causes of work delays are related to problems with contractor financing during construction and late payment of contractors by the owner. Marzouk and El-Rasas (2014) further recommend that a comprehensive cash flow and financing plan be developed for the venture, since the financial issues and the complete payment of the executed services are configured as one of the main focus of concern on the part of both the owners and the contracted companies.

\section{Factor IV: management of climatic conditions}

This last factor accounts for $9.344 \%$ of the total variance and has the following variable and comprises variables related to climate and weather conditions (heat, rain, etc.).

Weather conditions have a load factor of 0.960 and are characterized as one of the main causes of work delays; as attested by the studies by Senouci, Al Abbasi and Eldin (2018), who state that weather conditions have a high impact on labor productivity, especially temperature. Ahsan and Gunawan (2010) also consider that natural disasters should also be considered as critical causes of project delays. However, according to Ballesteros-Pérez et al. (2015), only a few studies have approached the climatic influences on open-air construction activities in detail.

It is observed that the data reported in such research do not differ from the reality in the northern region of Brazil, which has typical characteristics of the tropical climate, such as intense heat and high relative humidity, which influence significantly the planning of the works and facilitate the occurrences of delays to the original schedule, especially in the rainy season. 


\section{Conclusions}

The main objective of this paper was to study the delay in construction works and the analysis of the causes of this phenomenon by observing the correlations between them through the statistical factor analysis technique. The results demonstrated that the 12 causes of delay that were identified are correlated to only 4 delay factors, which account for $69.18 \%$ of the variance of the original data and have the eigenvalues of its components with significance, i.e., greater than 1:

(a) management $(21.41 \%)$;

(b) manpower management $(20.79 \%)$;

(c) project management (17.64\%); and

(d) management of climatic conditions $(9.34 \%)$.

It should be noted that the delay factors mentioned above can be considered as deficiencies in the management process of the works, which is considered to be one of the most relevant causes in the occurrence of time and cost deviations and influences all other categorizations in terms of coordination and decision making, a fact that is corroborated by several authors. Thus, the focus of coordination and decision making should be on managing the enterprise.

Therefore, it can be concluded that this research extended the knowledge of the area when performing the factor analysis of the causes of delay in construction works and not only the identification of the main causes, a common objective to several papers. And, mainly, it allowed for understanding how these causes relate to each other and the consequences of this correlation in the increment of the negative impacts of the construction work delays. Another contribution provided by this article is to have prompted a deep analysis on what issues should be prioritized in the strategies of actions that aim to minimize the occurrence of delays in the execution of projects in the civil construction; which directly influences the costs of the works, social issues, low quality, litigation and other consequences.

\section{Future works}

Finally, the execution of future research is recommended in order to prepare study proposals to minimize the impacts caused by the above-mentioned delay factors, mainly analyses focused on Production Planning and Control (PPC).

\section{References}

ABBAS, G.; PAINTING, N. Significant factors causing cost overruns in the construction industry in afghanistan. In: INTERNATIONAL CONFERENCE ON ENGINEERING, PROJECT, AND PRODUCTION MANAGEMENT, 7., Bialystok, 2017. Proceedings [...] Bialystok, 2017.

ABBASNEJAD, B.; MOUD, H. I. Construction delays in iranian civil engineering projects: an approach to the financial security of construction business. Life Science Journal, v. 10, n. 2, p. 2632-2637, 2013.

ABDUL-RAHMAN, H. et al. Delay mitigation in the malaysian construction industry. Journal of Construction Engineering and Management, v. 132, n. 2, p. 125-133, 2006.

ADAM, A.; JOSEPHSON, P. B. Aggregation of factors causing cost overruns and time delays in large public construction projects Trends and implications. Engineering, Construction and Architectural Management, v. 24, n. 3, p. 393-406, 2017.

AGYEKUM-MENSAH, G.; KNIGHT, A. D. The professionals' perspective on the causes of project delay in the construction industry. Engineering, Construction and Architectural Management, v. 24, n. 5, p. 828-841, 2017.

AHMED, S. M.; AZHAR, S.; KAPPAGANTULA, P. Delays in construction: a brief study of the florida construction industry. In: ASC ANNUAL CONFERENCE, 39., Miami, 2003. Proceedings [...] Miami, 2003.

AHSAN, K.; GUNAWAN, I. Analysis of cost and schedule performance of international development projects. International Journal of Project Management, v. 28, n. 1, p. 68-78, 2010. 
AIBINU, A. A.; JAGBORO, G. O. The effects of construction delays on project delivery in Nigerian construction industry. International Journal of Project Management, v. 20, n. 8, p. 593-599, 2002.

AKOGBE, R. K. T. M.; FENG, X.; ZHOU, J. Importance and ranking evaluation of delay factors for development construction projects in Benin. KSCE Journal of Civil Engineering, v. 17, n. 6, p. 12131222, 2013.

AL-MOMANI, A. H. Construction delay: a quantitative analysis. International Journal of Project Management, v. 18, n. 1, p. 51-59, 2000.

ALAGHBARI, W. et al. The significant factors causing delay of building construction projects in Malaysia. Engineering, Construction and Architectural Management, v. 14, n. 2, p. 192-206, mar. 2007.

ALSEHAIMI, A.; KOSKELA, L.; TZORTZOPOULOS, P. Need for Alternative research approaches in construction management: case of delay studies. Journal of Management in Engineering, v. 29, n. 4, p. 407-413, 2013.

ARANTES, A.; SILVA, P. F. da; FERREIRA, L. M. D. F. Delays in construction projects: causes and impacts. In: INTERNATIONAL CONFERENCE ON INDUSTRIAL ENGINEERING AND SYSTEMS MANAGEMENT, Seville, 2015. Proceedings [...] Seville, 2015.

ARDITI, D.; NAYAK, S.; DAMCI, A. Effect of organizational culture on delay in construction. International Journal of Project Management, v. 35, n. 2, p. 136-147, 2017.

ARDITI, D.; ROBINSON, M. A. Concurrent delays in construction litigation. Cost Engineering, v. 37, n. 7, p. 20-30, 1995.

ASNAASHARI, E. et al. Causes of construction delays in Iran : project management, logistics, technology and environment. In: ANNUAL ARCOM CONFERENCE, 25., Cardiff, 2009. Proceedings [...] Cardiff, 2009.

ASSAF, S. A.; AL-HEJJI, S. Causes of delay in large construction projects. International Journal of Project Management, v. 24, n. 4, p. 349-357, 2006.

AZIZ, R. F. Ranking of delay factors in construction projects after Egyptian revolution. Alexandria Engineering Journal, v. 52, n. 3, p. 387-406, 2013.

BALLESTEROS-PÉREZ, P. et al. Climate and construction delays: case study in Chile. Engineering, Construction and Architectural Management, v. 22, n. 6, p. 596-621, 2015.

BALLOU, R. H. Gerenciamento da cadeia de suprimentos/logística empresarial. 5. ed. Porto Alegre: Bookman, 2006.

BILGIN, G.; DIKMEN, I.; BIRGONUL, M. T. An ontology-based approach for delay analysis in construction. KSCE Journal of Civil Engineering, v. 22, n. 2, p. 384-398, 2018.

BIRGONUL, M. T.; DIKMEN, I.; BEKTAS, S. Integrated approach to overcome shortcomings in current delay analysis practices. Journal of Construction Engineering and Management, v. 141, n. 4, p. $04014088,2015$.

CHALLAL, A.; TKIOUAT, M. Identification of the causes of deadline slippage in construction projects : state of the art and application. Journal of Service Science and Management, v. 5, p. 151-159, jun. 2012.

CHAUHAN, K. A.; SHAH, N. C.; RAO, V. R. The analytic hierarchy process as a decision-support system in the housing sector : a case study. World Applied Sciences Journal, v. 3, n. 4, p. 609-613, 2008.

DOLAGE, D. A. R.; PATHMARAJAH, T. Mitigation of delays attributable to contractors in construction industry. Engineer, v. 48, n. 1, p. 21-30, 2015.

DOLOI, H. et al. Analysing factors affecting delays in Indian construction projects. International Journal of Project Management, v. 30, n. 4, p. 479-489, 2012.

DORAISAMY, S. V.; AKASAH, Z. A.; YUNUS, R. An overview on the issue of delay in the construction industry. Available:

https://www.researchgate.net/publication/300177825_An_Overview_on_the_Issue_of_Delay_in_the_Constr uction_Industry. Access: 16 apr. 2020.

DRESCH, A.; LACERDA, D. P.; ANTUNES JÚNIOR, J. A. V. Design science research. Porto Alegre: Bookman, 2015. 
DUY, N.; OGUNLANA, S. Large construction projects in developing countries : a case study from Vietnam. International Journal of Project Management, v. 22, p. 553-561, 2004.

EL-RAZEK, M. E. A.; BASSIONI, H. A.; MOBARAK, M. Causes of delay in building construction projects in Egypt. Journal of Management in Engineering, v. 11, n. 2, p. 831-841, 2008.

ENSHASSI, A.; ALNAJJAR, J.; KUMARASWAMY, M. Delays and cost overruns in the construction projects in the Gaza Strip. Journal of Financial Management of Property and Construction, v. 14, n. 2, p. 126-151, 2009.

FARIDI, A. S.; EL-SAYEGH, S. M. Significant factors causing delay in the UAE construction industry. Construction Management and Economics, v. 24, n. 11, p. 1167-1176, 2006.

FÁVERO, L. P. et al. Análise de dados multivariada. Rio de Janeiro: Elsevier, 2009.

FELLOWS, R.; LIU, A. Research methods for construction. $4^{\text {th }}$. ed. New York: John Wiley \& Sons, 2015.

FILIPPI, G. A. de; MELHADO, S. B. Um estudo sobre as causas de atrasos de obras de empreendimentos imobiliários na região Metropolitana de São Paulo. Ambiente Construído, Porto Alegre, v. 15, n. 3, p. 161173, jul./set. 2015.

FLYVBJERG, B. et al. Underestimating costs in public works projects: error or lie? Journal of the American Planning Association, v. 68, n. 3, p. 279-295, 2002.

FREITAS, H. et al. O Método da pesquisa Survey. Revista de Administração, v. 35, n. 3, p. 105-112, 2000.

FUGAR, F. D. K.; AGYAKWAH-BAAH, A. B. Delays in building construction projects in Ghana. Australasian Journal of Construction Economics and Building, v. 10, n. 1/2, p. 103-116, 2010.

GARDEZI, S. S. S.; MANARVI, I. A.; GARDEZI, S. J. S. Time extension factors in construction industry of Pakistan. Procedia Engineering, v. 77, p. 196-204, 2014.

GEBREHIWET, T.; LUO, H. Analysis of delay impact on construction project based on RII and correlation coefficient : empirical study. Procedia Engineering, v. 196, p. 366-374, jun. 2017.

GIL, A. C. Como elaborar projetos de pesquisa. $4^{\text {th. }}$ ed. São Paulo: Atlas, 2002.

GŁUSZAK, M.; LES̈NIAK, A. Construction delays in clients opinion: multivariate statistical analysis. Procedia Engineering, v. 123, p. 182-189, 2015.

GONZÁLEZ, P. et al. Analysis of causes of delay and time performance in construction projects. Journal of Construction Engineering and Management, v. 140, n. 1, p. 1-9, 2014.

GREEN, S. et al. Introduction. In: COCHRANE Handbook for Systematic Reviews of Interventions. Chichester: John Wiley \& Sons, 2008.

GÜNDÜZ, M.; NIELSEN, Y.; ÖSDEMIR, M. Quantification of delay factors using the relative importance index method for construction projects in Turkey. Journal of Management in Engineering, p. 133-139, apr. 2013.

GUNDUZ, M.; NIELSEN, Y.; OZDEMIR, M. Fuzzy assessment model to estimate the probability of delay in Turkish construction projects. Journal of Management in Engineering, v. 31, n. 4, p. 04014055, 2015.

HAIR JUNIOR, J. F. et al. Análise multivariada de dados. $6^{\text {th }}$. ed. Porto Alegre: Bookman, 2009.

HAMZAH, N. et al. Cause of construction delay: theoretical framework. Procedia Engineering, v. 20, p. 490-495, dec. 2011.

HASAN, A.; JHA, K. N. Client and contractor roles in schedule incentive/disincentive projects. Engineering, Construction and Architectural Management, v. 26, n. 3, p. 386-407, 2019.

HASEEB, M.; BIBI, A. Problems of projects and effects of delays in the construction industry of Pakistan. Australian Journal of Business and Management Research, v. 1, n. 5, p. 41-50, 2011.

HASMORI, M. F. et al. Significant factors of construction delays among contractors in Klang Valley and its mitigation. International Journal of Integrated Engineering, v. 10, n. 2, p. 32-36, 2018.

HSU, P.; AURISICCHIO, M.; ANGELOUDIS, P. Investigating schedule deviation in construction projects through root analysis. Procedia Computer Science, v. 121, p. 732-739, 2017. 
HWANG, B. G.; ZHAO, X.; NG, S. Y. Identifying the critical factors affecting schedule performance of public housing projects. Habitat International, v. 38, p. 214-221, 2013.

ILYAS, M.; LI, J.; ULLAH, I. Study of factors causing time and cost overrun in pre-construction project: a case study of Malaysia. World Journal of Engineering and Technology, v. 8, p. 1-12, dec. 2020.

IYER, K. C.; JHA, K. N. Factors affecting cost performance: evidence from Indian construction projects. International Journal of Project Management, v. 23, n. 4, p. 283-295, 2005.

KAMING, P. F. et al. Factors influencing construction time and cost overruns on high-rise projects in Indonesia. Construction Management and Economics, v.15, n. 1, p. 83-94, 1997.

KAZAZ, A.; ULUBEYLI, S.; TUNCBILEKLI, N. A. Causes of delays in construction projects in Turkey. Journal of Civil Engineering and Management, v. 18, n. 3, p. 426-435, 2012.

KEANE, P. J.; CALETKA, A. F. Analysis of construction delays. Hong Kong: Blackwell Publishing, 2008.

KHAHRO, S. H.; MEMON, Z. A. Non excusable delays in construction industry: a causal study. Engineering, Technology \& Applied Science Research, v. 8, n. 6, p. 3561-3564, 2018.

KHAN, R. A.; GUL, W. Empirical study of critical risk factors causing delays in construction projects. In: INTERNATIONAL CONFERENCE ON INTELLIGENT DATA ACQUISITION AND ADVANCED COMPUTING SYSTEMS: TECHNOLOGY AND APPLICATIONS, 9., Bucharest, 2017. Proceedings [...] Bucharest, 2017.

KHANZADI, M. et al. The less agents, the more schedule reliability: examination of single-point responsibility model in design management. International Journal of Civil Engineering, v. 17, n. 8, p. 1307-1316, 2019.

KHARASHI, A. et al. Causes of delays in Saudi Arabian public sector construction projects. Construction Management and Economics, v. 27, p. 3-23, fev. 2009.

KHOSHGOFTAR, M. et al. Causes of delays in iranian construction projects. International Journal of Construction Management, v. 10, n. 2, p. 53-69, 2010.

KIVINIEMI, M. et al. BIM-based safety management and communication for building construction. Espoo: VTT Tiedotteita, 2011.

KOG, Y. C. Major construction delay factors in Portugal, the UK, and the US. Practice Periodical on Structural Design and Construction, v. 23, n. 4, p. 04018024, 2018.

KOUSHKI, P. A.; KARTAM, N. Impact of construction materials on project time and cost in Kuwait. Engineering, Construction and Architectural Management, v. 11, n. 2, p. 126-132, 2004.

KOWALCZYK, A. et al. Delays in construction works in Polish construction industry from the contractors' point of view. In: MATEC WEB OF CONFERENCES, Poznan, 2018. Proceedings [...] Poznan, 2018.

KUMARASWAMY, M. M.; CHAN, D. W. M. Contributors to construction delays. Construction Management and Economics, v. 16, n. 1, p. 17-29, 1998.

LARSEN, J. K. et al. Factors affecting schedule delay, cost overrun, and quality level in public construction projects. Journal of Management in Engineering, v. 32, n. 1, p. 1-10, 2016.

MARTINS, P. G.; ALT, P. R. C. Administração de Materiais e Recursos Patrimoniais. 3. ed. São Paulo: Saraiva, 2009.

MARZOUK, M.; EL-DOKHMASEY, A.; EL-SAID, M. Assessing construction engineering-related delays: Egyptian perspective. Journal of Professional Issues in Engineering Education and Practice, v. 134, n. 3, p. 315-326, 2008.

MARZOUK, M. M.; EL-RASAS, T. I. Analyzing delay causes in egyptian construction projects. Journal of Advanced Research, v. 5, n. 1, p. 49-55, 2014.

MAUÉS, L. M. F. et al. Construction delays: a case study in the Brazilian Amazon. Ambiente Construído, Porto Alegre, v. 17, n. 3, p. 167-181, jul./set. 2017.

MEGHA, D.; RAJIV, B. A Methodology for ranking of causes of delay for residential construction projects in Indian context. International Journal of Emerging Technology and Advanced Engineering, v. 3, n. 3, p. 396-404, 2013. 
MOTA, R. Z. et al. Estudo sobre a ferramenta curva ABC em uma empresa de distribuição. Convibra, p. 18, 2012.

MUHWEZI, L.; ACAI, J.; OTIM, G. An assessment of the factors causing delays on building construction projects in Uganda. International Journal of Construction Engineering and Management, v. 3, p. 1323, feb. 2014.

MUIANGA, E. A. D.; GRANJA, A. D.; RUIZ, J. de A. Desvios de custos e prazos em empreendimentos da construção civil: categorização e fatores de influência. Ambiente construído, Porto Alegre, v. 15, n. 1, p. 79-97, jan./mar. 2015.

MUKUKA, M.; AIGBAVBOA, C.; THWALA, W. Effects of construction projects schedule overruns : A case of the Gauteng Province, South Africa. In: INTERNATIONAL CONFERENCE ON APPLIED HUMAN FACTORS AND ERGONOMICS (AHFE 2015) AND THE AFFILIATED CONFERENCES, 6. Las Vegas, 2015. Proceedings [...] Las Vegas, 2015.

MYDIN, M. O. et al. Assessment of influential causes of construction project delay in Malaysian private housing from developer's viewpoint. In: E3S WEB OF CONFERENCES, 3., Bangi, 2014. Proceedings [...] Bangi: EDP Sciences, 2014a.

MYDIN, M. A. O. et al. Imperative causes of delays in construction projects from developers' outlook. MATEC Web of Conferences, v. 10, p. 06005, 2014b.

ODEH, A. M.; BATTAINEH, H. T. Causes of construction delay: traditional contracts. International Journal of Project Management, v. 20, n. 1, p. 67-73, 2002.

OGUNLANA, S. O.; PROMKUNTONG, K.; JEARKJIRM, V. Construction delays in a fast-growing economy: comparing Thailand with other economies. International Journal of Project Management, $v$. 14, n. 1, p. 37-45, 1996.

PALIKHE, S.; KIM, S.; KIM, J. J. Critical success factors and dynamic modeling of construction labour productivity. International Journal of Civil Engineering, p. 1-16, 2018.

PARK, K. et al. Project Risk factors facing construction management firms. International Journal of Civil Engineering, v. 17, n. 3, p. 305-321, 2019.

PEREIRA, E. et al. Causas do atraso na entrega de edifícios residenciais Identification of critical SMS factors and accident precursors View project. 2011. Available:

https://www.researchgate.net/publication/236331998. Access: 25 mar. 2020.

POURROSTAM, T.; ISMAIL, A. Study of methods for minimizing construction delays: evidences from a developing country. Advanced Materials Research, v. 201-203, p. 2939-2942, 2011.

POURROSTAM, T.; ISMAIL, A.; MANSOURNEJAD, M. Identification of success factors in minimizing delays on construction projects in IAU - Shoushtar Branch - Iran. Applied Mechanics and Materials, v. 94-96, p. 2189-2193, 2011a.

POURROSTAM, T.; ISMAIL, A.; MANSOURNEJAD, M. Identification and evaluation of causes and effects of change orders in building construction projects. Applied Mechanics and Materials, v. 94/96, p. 2261-2264, set. 2011b.

PRASAD, K. V et al. Critical causes of time overrun in Indian construction projects and mitigation measures. International Journal of Construction Education and Research, p. 1-23, 2018.

RACHID, Z.; TOUFIK, B.; MOHAMMED, B. Causes of schedule delays in construction projects in Algeria. International Journal of Construction Management, v. 3599, 2018.

RAFIEIZONOOZ, M. et al. Determining the causes of delay by using factor analysis in Tehran's construction projects. Applied Mechanics and Materials, v. 735, p. 109-116, 2015.

RAHMAN, M. M. et al. Causes of shortage and delay in material supply: a preliminary study. In: IOP CONFERENCE SERIES: MATERIALS SCIENCE AND ENGINEERING, Moscow, 2017. Proceedings [...] Moscow, 2017.

RATHINAKUMAR, V.; VIGNESH, T.; DHIVAGAR, K. Perception of construction participants in construction delays: a case study in Tamilnadu, India. IOP Conference Series: Earth and Environmental Science, v. 80, n. 1, 2017. 
REIS, C. J. L. et al. Identificação das causas de atrasos de obras: um estudo de caso na região metropolitana de Belém. In: ENCONTRO NACIONAL DE TECNOLOGIA DO AMBIENTE CONSTRUÍDO, 16., São Paulo, 2016. Anais [...] São Paulo, 2016.

SAEB, S.; KHAYAT, N.; TELVARI, A. Causes of delay in Khuzestan steel company construction projects. Industrial Engineering and Management Systems, v. 15, n. 4, p. 335-344, 2016.

SAMARGHANDI, H. et al. Studying the reasons for delay and cost overrun in construction projects : the case of Iran. Journal of Construction in Developing Countries, v. 21, n. 1, p. 51-84, 2016.

SAMBASIVAN, M.; SOON, Y. W. Causes and effects of delays in Malaysian construction industry. International Journal of Project Management, v. 25, n. 5, p. 517-526, 2007.

SAMPAIO, R. F.; MANCINI, M. C. Estudos de revisão sistemática: um guia para síntese criteriosa da evidência científica. Brazilian Journal of Physical Therapy, v. 11, n. 1, p. 83-89, 2007.

SANTOS, H. de P.; STARLING, C. M. D.; ANDERY, P. R. P. Diagnóstico e análise de aditivos contratuais em obras públicas de edificações. In: ENCONTRO NACIONAL DE TECNOLOGIA DO AMBIENTE COSNTRUÍDO, 15., Maceió, 2014. Anais[...] Maceió, 2014.

SENOUCI, A.; AL ABBASI, M.; ELDIN, N. N. Impact of weather conditions on construction labour productivity in Qatar. Middle East Journal of Management, v. 5, n. 1, p. 34, 2018.

SENOUCI, A.; ISMAIL, A.; ELDIN, N. Time delay and cost overrun in Qatari public construction projects. Procedia Engineering, v. 164, p. 368-375, jun. 2016.

SEPASGOZAR, S. M. E.; RAZKENARI, M. A.; BARATI, K. The importance of new technology for delay mitigation in construction projects. American Journal of Civil Engineering and Architecture, v. 3, n. 1, p. 15-20, 2015.

SERNA, S. L. et al. Identificação de fatores que geram diferenças de tempo e custo em projetos de construção na Colômbia. Engenharia e Ciência, p. 1-21, 2018.

SHA, M. K. et al. Causes and effects of delays in constrution projets. Journal of Mechanical and Civil Engineering, v. 14, n. 2, p. 52-58, 2017.

SHAHSAVAND, P.; MAREFAT, A.; PARCHAMIJALAL, M. Causes of delays in construction industry and comparative delay analysis techniques with SCL protocol. Engineering, Construction and Architectural Management, v. 25, n. 4, p. 497-533, 2018

SHEBOB, A.; DAWOOD, N.; XU, Q. Analysing construction delay factors: a case study of building construction project in Libya. In: ANNUAL ARCOM CONFERENCE, 27., Bristol, 2011. Proceedings [...] Bristol, 2011.

SWEIS, G. Delays in construction projects : the case of Jordan. International Journal of Project Management, v. 26, p. 665-674, 2008.

TAFAZZOLI, M.; AP, L.; SHRESTHA, P. P. Investigating causes of delay in U.S. construction projects. In: ASC ANNUAL INTERNATIONAL CONFERENCE, 53., Las Vegas, 2017. Proceedings [...] Las Vegas, 2017.

TARIGAN, A. P.; SUBROTO, M. On the delay factors of the private construction projects in Medan city. IOP Conference Series: Earth and Environmental Science, v. 126, n. 1, 2018.

TOOR, S.-U.-R.; OGUNLANA, S. O. Problems causing delays in major construction projects in Thailand. Construction Management and Economics, p. 1-14, fev. 2008.

TORRES, G.; MONTEIRO, R.; ARICA, J. Confiabilidade em questionários para qualidade: um estudo com o coeficiente Alfa de Cronbach. Produto \& Produção, v. 11, n. 2, p. 85-103, 2010.

TRAUNER, T. J. et al. Construction delays: understanding them clearly, analyzing them correctly. $2^{\text {nd }}$. ed. San Diego: Elsevier Butterworth-Heinemann, 2009.

ULLAH, K. et al. Ranking of effects of construction delay: evidence from malaysian building projects. Journal of Applied Engineering Sciences, v. 8, n. 1, p. 79-84, 2018.

VACANAS, Y.; DANEZIS, C. An overview of the risk of delay in Cyprus construction industry. International Journal of Construction Management, p. 1-13, 2018. 
VENKATESH, P. K.; VENKATESAN, V. Delays in construction projects: a review of causes, need and scope for further research. Malaysian Construction Research Journal, v. 23, n. 3, p. 89-113, 2017.

YANG, J.-B.; CHU, M.-Y.; HUANG, K.-M. An empirical study of schedule delay causes based on Taiwan's litigation cases. Project Management Journal, v. 44, n. 3, p. 21-31, 2013.

YANG, J.-B.; WEI, P.-R. Causes of delay in the planning and design phases for construction projects. Journal of Architectural Engineering, v. 16, n. 2, p. 80-83, 2010.

ZIDANE, Y. J.-T. et al. Time-thieves and bottlenecks in the Norwegian construction projects. Procedia Economics and Finance, v. 21, n. 2212, p. 486-493, 2015.

\title{
Acknowledgements
}

This research was carried out with the support of the Coordenação de Aperfeiçoamento de Pessoal de Nível Superior - Brasil (CAPES) - Financing Code 001.

\section{André Brasil Carvalho}

Programa de Pós-Graduação em Engenharia Civil | Universidade Federal do Pará | Rua Augusto Corrêa, 01, Guamá | Belém - PA - Brasil | CEP 66075-110 | Tel.: (91) 3201-8859 | E-mail: andrebrasil@ufpa.br

\section{Luiz Maurício Furtado Maués}

Programa de Pós graduação em Engenharia Civil, Faculdade de Engenahria Civil | Universidade Federal do Pará | E-mail: maues@ufpa.br

\section{Felipe Moreira Sá}

Faculdade de Engenahria Civil | Universidade Federal do Pará | E-mail: samoreira@ufpa.br

\section{Caio José Losada Reis}

Programa de Pós-Graduação em Engenharia Civil | Universidade Federal do Pará | E-mail: caiojlreis@gmail.com

\author{
Ambiente Construído \\ Revista da Associação Nacional de Tecnologia do Ambiente Construído \\ Av. Osvaldo Aranha, $99-3^{\circ}$ andar, Centro \\ Porto Alegre - RS - Brasil \\ CEP $90035-190$ \\ Telefone: +55 (51) 3308-4084 \\ www.seer.ufrgs.br/ambienteconstruido \\ www.scielo.br/ac \\ E-mail: ambienteconstruido@ufrgs.br
}

(c) (1)

This is an open-access article distributed under the terms of the Creative Commons Attribution License.

46 Carvalho, A. B.; Maués, L. M. F.; Moreira, F. de S.; Reis, C. J. L. 